\title{
A Gift and Exchange Division in Wartime
}

This article by the chief of the Gift and Exchange Division of the University of California at Berkeley, like preceding ones from California, embodies a report on conditions incident to the war in a particular division of university library activity.

$\mathrm{O}$ NE OF THE MAJOR PROBLEMS confronting librarians at the present time is the possible fate of serials and monographic publications emanating from the countries across the Atlantic and Pacific. How has the war affected their receipt here? What are the prospects for the postwar era? So far as materials obtained by purchase are concerned, the head of the accessions department is best qualified to make a report for the University of California, since that unit is responsible for their acquisition.

Turning to serials received by gift or exchange, however, there is, of course, a very large percentage which have suspended. Others are appearing at more or less regular intervals but are not coming to the United States. Some have undoubtedly ceased, but the prophecy may be ventured that a surprising number will gradually recover their places on the shelves within a few years after peace is restored. This conjecture is based upon actual experience with the collection of the University of California $\mathrm{Li}$ brary after World War I and upon respect for man's ability to rise again after major catastrophes. In fact, he has already started upon a return journey. Spain is once more publishing important periodicals and docu- ments, in addition to monographic works. Recently liberated territories, such as Algiers, have expressed their desire to resume and even expand their exchange relations. A shipment from Syria a few weeks ago included studies from I940 through 1943. These evidently had been delayed on account of the exigencies of war. Similar examples can doubtless be cited by other institutions. From the British Isles publications have arrived with amazing regularity, although the output is limited. The Soviet Union will be discussed as a unit. It seems to keep an even keel, come what may.

At the outbreak of hostilities, the Smithsonian Institution in Washington, D.C., suspended shipping operations abroad. Since most of the University of California Press publications are forwarded via this' intermediary, the press agreed to reserve a sufficient number of copies from the current output in the scientific series to provide for exchanges through it. It is satisfying to know that it will be possible thereby to assist in building up the sadly depleted resources of educational institutions in war-devastated countries. Foe as well as friend will benefit, moreover, for investigations, discoveries, and inventions recognize no boundary lines. Furthermore, there should be received in return the publications of the present enemies of the United States, thus assuring familiarity with wartime developments in their countries.

Early in I94I the library undertook to notify foreign exchanges that the press was 
earmarking current material and asked for similar action from the institutions to which the letters were addressed. Many favorable replies were received before communications were cut off. The query that immediately comes to mind is, "How much of this solicited material will be in existence when hostilities cease ?" It remains to be seen.

When all that was feasible had been done to ensure receipts, the division turned its attention to the channels that are still open. One of the interesting facts in connection with this tragic era is the surprising number of new publications, both serial and monographic, that continue to appear in spite of the doors which have been slammed shut. Titles spring up like mushrooms with, of course, a veritable deluge of propaganda. All parts of the library are cooperating in the acquisition of this type of material. Likewise, the various units are diligently gleaning the worth-while publications which may be of assistance in the difficult years that lie ahead in the postwar period. Incidentally, there has been received recently a monthly bulletin emanating from the Society. for Prevention of World War III.

\section{Russian Publications}

We now turn to Russian serials and monographs. Since there already was a good basic collection of prerevolutionary material, thanks to the foresight of such authorities as Professor G. R. Noyes, Professor R. J. Kerner, and the late Professor Alexander Kaun, the effort has been in recent years to develop and expand this nucleus by obtaining, through exchange, publications issued since 1917. It has been gratifying, therefore, to note the use made of the collection as a whole by government officials and scholars in general during the present crisis. The Soviet Union, moreover, has continued to carry on its program of research. Important new works appear in every bibliography that reaches the shelves. Many of these have already been requested and received here. Perhaps more remarkable has been the recent arrival of some issues of a series emanating from the University of Kazan, dating back to $189 \mathrm{I}$, to fill in lacunae. For years the two well-known agents, the Vsesoiuznoe Obshchestvo Kul'turnoi Sviazi s Zagranitsei and the Vsesoiuznaia Biblioteka imeni Lenina, have been furnishing sets of various serials, item by item; but to be supplied with these in the midst of such turmoil is surprising indeed. Evidently the efforts made to make contact with Russian exchanges during the war have impressed the recipients of the letters, since a commentator from the famous public library of Leningrad writes in the Library World as follows:

Even during the difficult days of the siege, letters from the University of California ... by some miraculous means found their way to the library. At the present time a regular correspondence and interchange of books is maintained between these institutions. ${ }^{1}$

From the Orient let us put on sevenleague boots and leap to Latin America. While the University of California Library has been adding publications from the lands to the south for many years, the pace was accelerated considerably in $194 \mathrm{I}$ in the hope of getting a little ahead of the interest in these countries, which is rapidly developing and supposedly will continue to increase in the postwar era. At the present time there are some 958 serials, exclusive of documents and the files maintained by the Bancroft Library. (This figure includes a small percentage acquired by purchase, but the majority have come by gift or exchange.) In addition, many monographs have been obtained. However, much remains to be done before the collection can be said to be thoroughly representative. It may be well to point out in this connection that the library is interested primarily in the quality of the

${ }^{1}$ Library World 46:135-36, April 1944. 
works that are added rather than in the quantity. As far as serial publications are concerned, hundreds of requests are sent for sample copies in order that the publications may be examined by competent authorities before a definite attempt is made to secure files. The cooperation received from our southern neighbors in the systematic efforts to develop the collection has been gratifying.

\section{Gift Collections}

Finally we come to the role played by the gift collections that pour in during war days as well as in peacetime. As every institution knows, these vary from a few items to donations of several hundred volumes. They may be pamphlets of little.interest to anyone except the donor or they may be works that would make a collector's mouth water. It has been said that the handling of gifts is an expensive proposition in a large institution, since only a comparatively small percentage will be absorbed by the recipient. True enough, but the fundamental situation remains the same. Either libraries must refuse to accept gifts or they must continue to accept them and dispose of them to the best advantage. There is no halfway measure.

The university in Berkeley is fortunate inasmuch as it has other campuses with smaller collections or specialized interests which usually welcome duplicates. In connection with the latter, emphasis is being laid by the loan and shelf division upon replacement of worn-out copies of foreign publications and even the addition of extra copies, since this type of material will be difficult to procure in the future. Reserve sets of serials are also being accumulated and stored for the years to come, together with duplicates of monographs which may be of service for the proposed library for undergraduates.

One of the regrettable casualties of the war, due to a war budget, is the duplicate list prepared for distribution to other institutions. Thousands of items were formerly placed where they would be of service, in return for similar courtesies. The most that can be done along these lines at the present time is to send out post cards offering back numbers of important serials to libraries which indicate lacunae in the Union List of Serials. It is often surprising to find some of the large institutions accepting offers with alacrity, and the library feels repaid for the work involved, even though this is superimposed upon an already crowded program.

Needless to say, the men in service are not forgotten. Books which will be of interest to them are dispatched to camps. Since, however, certain types of publications are of problematical usefulness, arrangements have been made with the librarian of a large naval unit near by to scan shelves of duplicates collected, for appraisal in order that her library may not be burdened with material that is of no value to the Navy personnel. The same arrangement has been made with one of the large housing units, because this represents a cross section in age, interest, and background.

The general library also cooperates with the A.L.A. Committee on Aid to Libraries in War Areas and has already deposited a number of runs of periodicals in storage places designated by the committee. China has received special attention from the library as well as from other parts of the university.

This then is an effort to present in a brief paper the main activities of the division in connection with the library as a whole. Special emphasis has been laid upon the groundwork for the postwar era, since surely this is of paramount importance for libraries everywhere if we are to do our part in the difficult years which are bound to follow close upon the heels of peace. 